\title{
CURRENT CONCEPTS IN ENDOCRINOLOGY FOR CLINICIANS AND MEDICAL STUDENTS HASHIMOTO'S THYROIDITIS: CLINICAL AND SUBCLINICAL THYROID DYSFUNCTION
}

\section{CONCEITOS ATUAIS NA ENDOCRINOLOGIA PARA OS CLÍNICOS E ESTUDANTES DE MEDICINA TIREOIDITE DE HASHIMOTO: DISFUNÇÃO TIREOIDIANA CLÍNICA E SUBCLÍNICA}

\author{
Paulo Travassos Neto*, \\ Janeiro, Brazil. \\ E-mail address for correspondence: ptravassos3@gmail.com \\ Type of manuscript: mini review
}

* Medicine School, Endocrinology Unit, Internal Medicine Department, Fluminense Federal University, UFF, Niterói, Rio de

\begin{abstract}
Hashimoto's thyroiditis (HT) is an autoimmune and inflammatory disease in which antibodies are directed against the thyroid gland leading to chronic inflammation and hypothyroidism. The autoimmunity against thyroid antigens can be associated to genetic background and environmental factors. Thyroid peroxidase (TPO) and thyroglobulin (TG) are the major autoantigens for characterizing the disease. And the pathogenic mechanism is related to the activation of autoreactive $\mathrm{CD} 4^{+} \mathrm{T}$ cells, $\mathrm{CD} 8^{+}$cytotoxic $\mathrm{T}$ cells and antithyroid antibody producing-B cells. The treatment for hypothyroidism is based on thyroid hormone replacement, the levothyroxine. This review briefly discusses the clinical and pathogenic profile of HT and the importance of a correct diagnostics.

Key words: Hashimoto's thyroiditis, hypothyroidism, diagnostic, treatment
\end{abstract}

\begin{abstract}
RESUMO
A tireoidite de Hashimoto (TH) é uma doença autoimune e inflamatória na qual os anticorpos são direcionados contra a glândula tireoide, levando à inflamação crônica e ao hipotireoidismo. A autoimunidade contra antígenos tireoidianos pode estar associada a fatores genéticos e ambientais. A peroxidase tireoidiana (TPO) e a tireoglobulina (TG) são os principais autoantígenos, responsáveis muitas vezes pelo diagnóstico da doença, que é complementado com outras análises laboratoriais e clínicas. A resposta imunológica evidenciada na $\mathrm{TH}$ envolve ativação de células T CD4 ${ }^{+}$auto-reativas, células T citotóxicas $\mathrm{CD}^{+}$e células $\mathrm{B}$ produtoras de anticorpos antitireoidianos. $\mathrm{O}$ tratamento mais comum do hipotireoidismo consiste na reposição do hormônio levotiroxina. Esta revisão discute brevemente o perfil clínico e patogênico da $\mathrm{TH}$ e a importância de um diagnóstico correto.

Palavras-chave: Tireoidite de Hashimoto, hipotireoidismo, diagnóstico e tratamento.
\end{abstract}




\section{INTRODUCTION}

Autoimmune thyroid diseases (AITD) constitute $30 \%$ of all the autoimmune conditions and are classified as organ specific diseases. Hashimoto's thyroiditis (HT), described in 1912 by Hakaru Hashimoto, is considered a multifactorial disease group in which antibodies are directed against the thyroid gland. The antithyroid antibodies attack thyroid stroma, causing progressive fibrosis and leading to chronic inflammation and hypothyroidism. The most common antibodies are anti-thyroid peroxidase (TPO) and anti-thyroglobulin (TG) and, in some cases it is possible to detect thyroid stimulating hormone (TSH) receptor blocking antibodies (anti-TSHR) (Pyzik A, 2015; Antonelli A, 2015; Chistiakov DA, 2005). The etiology of HT is still poorly understood, but the autoimmunity against thyroid antigens has been related to the genetic and environmental factors and the disorder is prevalent in individuals aged $>60$ years, with a female/male ratio ranging from 5:1 to 10:1 (Yoo WS, 2016).

\section{PATHOLOGY AND DIAGNOSIS}

The hypothyroidism is traditionally defined as deficient thyroidal production of thyroid hormone by factors affecting the thyroid gland itself; the fall in serum concentrations of thyroid hormone causes an increased secretion of TSH resulting in elevated serum TSH concentrations and, can also be caused by insufficient stimulation of the thyroid gland by TSH, due to factors directly interfering with pituitary TSH release or indirectly by diminishing hypothalamic thyrotropin-releasing hormone (TRH) release (Lee HJ, 2015; Yoo WS, 2016; Mincer, DL, 2017).

Histologically and clinically, HT is characterized by fibrosis, lymphoplasmacytic infiltration, degeneration of follicular cells and rapid progression of hypothyroidsm. The pathologic examination commonly shows a symmetric enlargement of the thyroid and, it can appear to be diffuse. Interlobular fibrosis may or may not be present. In some cases, the gland may become nodular or asymmetric (Pyzik A, 2015). Initially, patients may have bouts of hyperthyroid symptoms, as the initial destruction of thyroid cells may lead to release thyroid hormones into the bloodstream. These symptoms are varied and may affect almost any organ system in the body (Pearce EN, 2003 Cooper DS, 2012; Effraimidis G, 2014).

The diagnosis of HT is based on the increase of anti-TPO and anti-TG serum levels and the typical clinical signs are associated to the change in the ultrasonographic aspects of the thyroid gland (Ben-
Skowronek I, 2013; Effraimidis G, 2014). Thyroidstimulation hormone (TSH) is raised due to Hashimoto thyroiditis and in primary hypothyroidism that is based in low total T4 and low free T4 in the presence of an elevated TSH level (Mincer, DL, 2017; Cooper DS, 2012). Although definite diagnostic criteria are not yet available, >20 IgG4-positive plasma cells per highpower field and $>30 \%$ IgG4-positive/IgG-positive plasma cells have been proposed as additional diagnostic criteria for HT (Jokisch F, 2016). A thyroid ultrasound assesses thyroid size, echotexture, and whether thyroid nodules are present. If HT is suspected and nodules are palpable or found on ultrasound, fine-needle aspiration on thyroid nodules can be performed to exclude malignancy or the presence of a thyroid lymphoma (Brand OJ, 2009; Mikos H, 2014).

A study with 290 HT patients without LT4 treatment showed that elevated TGAb levels are associated with symptom burden, suggesting a role of thyroid autoimmunity in clinical manifestations of HT and recommending a screening for TGAb for better clinical follow-up of the patient (Baric, 2018).

Although we have several up-to-date management guidelines for "subclinical" hypothyroidism, the decision for a correct treatment is still vague aspect (Ben-Skowronek I, 2013; Pyzik A, 2015). Considering the progressive changes in the levels of serum TSH and free thyroxine (T4), has been suggested a better way to classify and to differentiate "clinical" and "subclinical" forms of hypothyroidism (Pearce SH, 2013; Wiersinga WM, 2015). Subclinical thyroid dysfunction comprises subclinical hypothyroidism, defined as elevated TSH by normal free T4 (FT4), and subclinical hyperthyroidism with decreased or undetectable TSH and normal FT4. Up to $10 \%$ of the elderly have subclinical hypothyroidism, which is usually asymptomatic (Wiersinga WM, 2015). The cardiovascular system is one of the main target organs of thyroid hormones and elevated or decreased TSH levels can adversely affect the cardiovascular system (Floriani C, 2018; Jing Sun, 2017). The influence of thyroid hormones (THs) on the cardiovascular system involves the regulation of key processes related to maintenance of cardiac function. Some studies demonstrated that subclinical hypothyroidism increased cardiovascular risk factors including altered lipid profile, insulin resistance, oxidative stress, increased vascular stiffness, and endothelial dysfunction (Jing Sun et al, 2017). Thus, the treatment with THs in patients with hypothyroidism improves cardiovascular risk 
factors (H. Vargas-Uricoechea, 2014; J. Wu, 2016).

\section{PATHOGENIC MECHANISMS}

The HT is one of the most prevalent human autoimmune diseases, responsible for high morbidity in women. The antithyroid inflammatory reaction in HT is enhanced by several mechanisms, counting on the participation of autoreactive $\mathrm{CD} 4^{+} \mathrm{T}$ cells, $\mathrm{CD} 8^{+}$ cytotoxic $\mathrm{T}$ cells and anti-thyroid antibodies producing-B cells. An influx of the lymphoid cells, dendritic cells and macrophages into thyroid occurs as a consequence of inflammatory events (Antonelli A, 2015; Ben-Skowronek, 2013). The disease is a result of a Th1 immune response which triggers cell mediated immunity and thyroid follicular cell death by apoptosis. Activated antigen-specific T-helper $\mathrm{CD} 4{ }^{+}$cells participate in the activation of intra-thyroid cytotoxic $\mathrm{CD}^{+} \mathrm{T}$ effector cells, B cells, which differentiate and produce autoantibodies (Zeppa P, 2006; Ates I, 2014; Mincer DL, 2017). Previous studies had already a prominent role of Th17 $\left(\mathrm{CD} 4{ }^{+} \mathrm{IL}-17^{+}\right)$and Treg lymphocytes $\left(\mathrm{CD} 4{ }^{+} \mathrm{CD} 25^{+}\right.$highFox $\left.3^{+}\right)$respectively in the induction and modulation of autoimmune reactions (Korn T, 2009; Zake T, 2018). With a very similar immunopathogenic profile, other different autoimmune diseases have been associated, such as vitiligo, rheumatoid arthritis, multiple sclerosis, Sjogren's syndrome, among others. Although the etiopathogenesis is still unknown, the importance of epigenetic modifications associated with environmental factors has been discussed (Antonelli \& Benvenga, 2018).

Besides that proinflammatory cytokines, which are synthesized by Th1 lymphocytes, often play a role in pathogenesis of autoimmune diseases. These proinflammatory cytokines increase the immunogenicity of antigenic structures in thyroid gland and similar tissues, which results in increased levels of IL-4, IL-5 and B lymphocytes (Zeppa P, 2006; Brenta G, 2013; Mikos H, 2014; Shen P, 2014; Pyzik A, 2015). Studies indicate that tumor necrosis factors alpha (TNF-alpha), superfamily cytokines such as B cell activation factor (BAFF; also known as BlyS) and a proliferation-inducing ligand (APRIL) are another important cytokines which can be involved in the establishment and/or maintenance of autoimmune diseases including systemic lupus erythematosus (SLE), rheumatoid arthritis (RA), diabetes and HT (Tan SM, 2003; Morel J, 2009; Fabris M, 2010; Vincent FB, 2014; Carvalho-Santos, 2015; Pinna, RA, 2018).

\section{TREATMENT}

Since Hakaru Hashimoto first described AITD in 1912, signifi-cant progress has been made about chron-ic autoimmune inflammatory condition in the thyroid. The treatment for HT is based on thyroid hormone replacement and the drug of choice is titrated levothyroxine sodium administered orally. Surgery is considered for a large goiter with obstructive symptoms such as dysphagia, hoarseness, and stridor, or a malignant nodule, a lymphoma, or for large, unsightly goiters (Brenta G,2003; Pyzik A, 2015; Mincer DL, 2017). In the context of the autoimmune response in HT some studies have shown that the treatment via selenium supplementation may be associated with the decrease in the levels of anti-TPO. Further it has also been shown a decrease in symptoms from a diet with adequate amounts of vitamin D and selenium (Mazokopakis EE, 2015; Liontiris MI, 2017, Rayman, 2018).

Recently, a therapeutic strategy was shown from intrathyroidal injection of glucocorticoid in patients with HT, presenting pain (Paja, 2018). Different therapeutic approaches have been suggested to attend the symptoms presented, often in a particular way by patients with thyroid disease.

\section{FINAL CONSIDERATIONS}

Hashimoto's thyroiditis (HT) is one of the most common human autoimmune diseases responsible for considerable morbidity in women. This mini-review emphasizes the importance of a correct diagnosis and ongoing research on the etiopathogenesis of thyroid diseases, as well as their association with other chronic diseases. In order to improve protocols for clinical and therapeutic follow-up for asymptomatic and symptomatic patients, always seeking a better quality of life, reducing the risks of comorbidities.

\section{ACKNOWLEDGEMENTS:}

I would like to thank Dr. Adriana CarvalhoSantos (pharmaceutical and postdoctoral by Fiocruz, IOC, RJ) for the collaboration in the development of this work. 


\section{REFERENCES:}

Pyzik A, Grywalska E, Matuszek B, Rolinski J. Immune Disorders in Hashimoto's Thyroiditis: What Do We Know So Far? J Immunol Res. 2015; 979167. DOI: 10.1155/2015/979167.

Antonelli A, Ferrari SM, Corrado A, Di Domenicantonio A, Fallahi P. Autoimmune thyroid disorders. Autoimmun Rev 2015; 14:174-180.

Chistiakov DA: Immunogenetics of Hashimoto's thyroiditis. J Autoimm Dis 2005; 11;2(1):1. DOI: 10.1186/1740-2557-2-1. Yoo WS, Chung HK. Recent Advances in Autoimmune Thyroid Diseases. Endocrinol Metab 2016; 31(3):379-385. DOI: 10.3803/EnM.2016.31.3.379.

Lee HJ, Li CW, Hammerstad SS, Stefan M, Tomer Y. Immunogenetics of autoimmune thyroid diseases: A comprehensive review. J. Autoimmun. 2015; 64:82-90.

Mincer DL, Jialal I. Hashimoto Thyroiditis. StatPearls Publishing; 2018.

Pearce EN, Farwell AP, Braverman LE. Thyroiditis. N Engl J Med 2003; 348:2646-2655.

Cooper DS, Biondi B: Subclinical thyroid disease. Lancet 2012; 379:1142-1154.

Effraimidis G, Wiersinga W. Mechanisms in endocrinology: autoimmune thyroid disease: old and new players. Eur J

Endocrinol 2014; 170:241-52.

Ben-Skowronek I, Szewczyk L, Kulik-Rechberger B, Korobowicz E. The differences in T and B cell subsets in thyroid of children with Graves' disease and Hashimoto's thyroiditis. W J Pediat 2013; 9(3):245-250.

Jokisch F, Kleinlein I, Haller B, Seehaus T, Fuerst H, Kremer M. A small subgroup of Hashimoto's thyroiditis is associated with IgG4-related disease. Virchows Arch 2016; 468(3):321-7.

Brand OJ, Barrett JC, Simmonds MJ, Newby PR, McCabe CJ, Bruce CK. Association of the thyroid stimulating hormone receptor gene (TSHR) with Graves' disease. Hum Mol Genet. 2009; 18:1704-13.

Mikos H, Mikos M, Obara-Moszynska M, and Niedziela M. The role of the immune

system and cytokines involved in the pathogenesis of autoimmune thyroid disease (AITD). Endokrynol Pol 2014: 65(2): p. 150-5.

Bariæ A, Brèiæ L, Graèan S, Škrabiæ V, Brekalo M, Šimunac M, Lovriæ VT, Aniæ, Barbaliæ M, Zemunik T, Punda A, Boraska Perica V. Thyroglobulin Antibodies are Associated with Symptom Burden in Patients with Hashimoto's Thyroiditis: A Cross-Sectional Study. Immunol Invest. 2018; 17:1-12. DOI: 10.1080/08820139.2018.1529.

Wiersinga WM. Guidance in subclinical hyperthyroidism and subclinical hypothyroidism: are we making progress? Eur Thyroid J 2015; 4:143-8.

Floriani C, Gencer B, Collet TH, Rodondi N. Subclinical thyroid dysfunction and cardiovascular diseases. Eur Heart J. 2018: 39(7): 503-507.DOI:10.1093/eurheartj/ehx050.

Sun J, Yao L, Fang Y, Yang R, Chen Y, Yang K, Tian L. Relationship between Subclinical Thyroid Dysfunction and the Risk of Cardiovascular Outcomes. A Systematic Review and Meta-Analysis of Prospective Cohort Studies. Int J Endocrinol 2017: 2017:8130796. doi: 10.1155/2017/8130796.

Vargas-Uricoechea H, Bonelo-Perdomo A, Sierra-Torres C. H. Effects of thyroid hormones on the heart. Clin Invest Arteriosclerosis 2014; 26:296-309.

J. Wu, Y. Tao, H. Gu, J. Sui. Association between cardiovascular risk factors and serum thyrotropin concentration among healthy Chinese subjects and subjects with unsuspected subclinical hypothyroidism. Clinl Lab 2016; 62: 807-814.

Zeppa P, Marino G, Lepore M, Troncone G, Lupoli GA, Biondi B, Picardi M, Pane F, Vetrani A, Palombini L. Flow cytometry phenotypization of thyroidal lymphoid infiltrate and functional status in Hashimoto's thyroiditis. Analytic Quantit Cytol Histol 2006;28(3):148-156.

Ates I, Ozkayar N, Akyel F. The relationship between asymptomatic organ damage, and serum soluble tumor necrosis factor-like weak inducer of apoptosis (sTWEAK) and Interleukin-17A (IL-17A) levels in non-diabetic hypertensive patients. BMC Nephrology, 2014; 15(1): 159.

Korn T, Bettelli E, Oukka M, Kuchroo VK. IL-17 and Th17 cells. Ann Rev Immunol 2009;27:485-517.

Zake T, Skuja S, Kalere I, Konrade I, Groma V. Heterogeneity of tissue IL-17 and tight junction proteins expression demonstrated in patients with autoimmune thyroid diseases. Medicine 2018; 97(25).

Antonelli A, Benvenga S. The Association of other autoimmune diseases in patients with thyroid autoimmunity. Frontiers Endocrinol 2018; 9:1-4.

Brenta G, Vaisman M, Sgarbi JA, Bergoglio LM, Andrada NC, Bravo PP, Orlandi AM, Graf H. Clinical practice Guidelines for management of hypothyroidism. Arq Bras Endocrinol Metab 2013; 57(4):265-299.

Shen P, Roch T, Lampropoulou V, O'Connor RA, Stervbo U, Hilgenberg E, Ries S, Dang VD, Jaimes Y, Daridon C, Li R, Jouneau L, Boudinot P, Wilantri S, Sakwa I, Miyazaki Y, Leech MD, McPherson RC, Wirtz S, Neurath M, Hoehlig K, Meinl E, Grützkau A, Grün JR, Horn K, Kühl AA, Dörner T, Bar-Or A, Kaufmann SHE, Anderton SM, Fillatreau S. IL-35-producing B cells are critical regulators of immunity during autoimmune and infectious diseases. Nature 2014; 507(7492):366-370. 
Tan SM, Xu D, Roschke V, Perry JW, Arkfeld DG, Ehresmann GR, Migone TS, Hilbert DM, Stohl W. Local production of B lymphocyte stimulator protein and APRIL in arthritic joints of patients with inflammatory arthritis. Arthritis Rheum 2003; 48:982-992.

Morel J, Roubille C, Planelles L, Rocha C, Fernandez L, Lukas C, Hahne M, Combe B. Serum levels of tumor necrosis factor family members a proliferation-inducing ligand (APRIL) and B lymphocyte stimulator (BLyS) are inversely correlated in systemic lupus erythematosus. Ann Rheum Dis 2009; 68:997-1002.

Fabris M, Grimaldi F, Villalta D, Piciemo A, Fabro C, Bolzan M, De Vita S, Tonutti E. BLyS and April serum levels in patients with autoimmune thyroid diseases. Autoimmunity Reviews 2010; 9:165-169.

Vincent FB, Morand EF, Schneider P, Mackay F. The BAFF/APRIL system in SLE pathogenesis. Nat Rev Rheumatol 2014; 33. DOI:10.1038/nrrheum.2014.33.

Carvalho-Santos A, Ribeiro-Alves M, Cardoso-Weide LC, Nunes J, Kuhnert LRB, Xavier AR. Villa-Verde DMS, CarvalhoPinto CE. Decreased circulating levels of APRIL: questioning its role in diabetes. Plos One. 2015; 10:, p.e0140150.

Pinna, RA; Dos Santos, AC; Perce-da-Silva, DS; da Silva, LA; da Silva, RNR; Alves, MR; Santos, F; de Oliveira-Ferreira, J; Lima Júnior, JC; Villa-Verde, DM; De Luca, PM; Carvalho-Pinto, CE; Banic. DM. Correlation of APRIL with production of inflammatory cytokines during acute malaria in the Brazilian Amazon. Immun Inflamm Dis. 2018; (3): 1-14.

Mazokopakis EE, Papadomanolaki MG, Tsekouras KC, Evangelopoulos AD, Kotsiris DA, Tzortzinis AA. Is vitamin D related to pathogenesis and treatment of Hashimoto's thyroiditis? Hell J Nucl Med. 2015; 18(3):222-7.

Liontiris MI, Mazokopakis EE. A concise review of Hashimoto thyroiditis (HT) and the importance of iodine, selenium, vitamin D and gluten on the autoimmunity and dietary management of HT patients.Points that need more investigation. Hell J Nucl Med. 2017; 20(1):51-56.

Rayman MP. Multiple nutritional factors and thyroid disease, with particular reference to autoimmune thyroid disease. Proc Nutr Soc. 2018; 13:1-11. DOI: 10.1017/S0029665118001192.

Paja M, Del Cura JL. Successful treatment of painful Hashimoto's thyroiditis with intrathyroidal injection of glucocorticoid in two patients. Endocrinol Diabetes Nutr. 2018; 65(9):546-547. DOI: 10.1016/j.endinu.2018.07.002. 